\title{
ベトナム・ハノイ市におけるぺ RECENT BUILDING SYSTEM OF ンシル住宅生産の実態調査 PENCIL HOUSES IN HANOI, VIETNAM
}

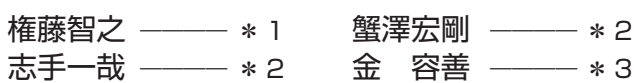

キーワード :

ハノイ, 在来構法, ペンシル住宅，生産システム，材料流通

Keywords:

Hanoi, Conventional construction, Pencil house, Building system, Materials
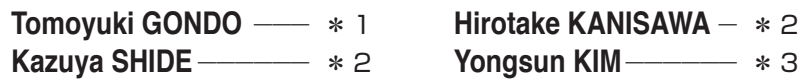

In this study, we focus on the building system of "Pencil houses" in Hanoi, Vietnam. Pencil houses are conventional houses: about five story reinforced concrete structure in urban narrow plot. Building pencil houses, households order a small worker team to build structural parts of pencil houses. These team, by themselves, can build large parts of houses including foundation, concrete forms, steel bars, casting concrete, laying brick walls, and plasters. We interviewed with ten these teams, two small construction companies, among others in Hanoi, and make clear the pencil house construction process, contracts system, and workers condition.

\section{1.はじめに}

\section{1 研究の目的}

本研究の目的は、ベトナム・ハノイ市において広く建設される 5 階建て程度のペンシル住宅（2 章後述）を対象とし、その構法的な 特徵を整理した上で、現在どのような建築生産が行われているかを 明らかにすることである。

ペンシル住宅については、ハノイの都市住宅を扱った佐々木、篠 崎らの一連の研究文2)、文3)があり、ペンシル住宅は伝統的町家、ヴィ ラ、集合住宅と並ぶ一般的な住宅類型として位置づけられ、間口が 狭く奥行きの長い平面計画上の特徴や、住民による住みこなしの実 態が明らかにされている。また、近年のベトナム都市部の住宅生産 を取り上げた研究として、ロアン文4) は八ノイ市Giap-bat 区の住宅 36 棟の生産方式について、施主が材料支給や施工管理に関わる割合 の高さを報告している注1)。しかし、実際に建築生産を担う主体を対 象とした調查に基づき、住宅の構法や施工法、コストまで含めて住 宅生産の実態を明らかにした既往の研究は希少である注2)。経済発展 が著しく建築生産にも今後変化が予想されるべトナムにおいて、建 築生産の現状を記録することの意義は大きいと考えられる。

\section{2 研究の方法}

本研究では、ペンシル住宅の躯体工事に労務を提供する非法人の 職人の集団を躯体チームと呼び、これを主たる対象としたインタビ ユー調査を実施した。躯体チームに対してインタビューを行うこと で、躯体工事を中心にペンシル住宅の構法、職人の待遇、材料の入 手方法等、ペンシル住宅生産全体のおおまかなあり様を把握するこ とができる。同時に躯体以外の職種についても、材料流通業者等へ のインタビューから概要を把握した。また、設計事務所 $\mathrm{A} 1$ 社が設計 したペンシル住宅 1 棟については、施主と躯体チームの契約書、施 主の施工管理記録ノートも入手し、これも分析に用いた注3)。
調査対象は、躯体チーム 10 チーム（B1〜B10 チーム）および躯体 チームを管理して住宅施工を行う施工会社 2 社（C1、C2 社）、一般 建築を施工する施工会社 1 社 (C3 社)、住宅設計を行う設計事務所 3 社（A1〜 A3 社）、材料流通業者 10 者（法人化していない主体が含ま れるため、者と表記する)、建築系研究機関である。また身体チーム については、ペンシル住宅 20 棟程度の施工現場を調查し、構法等の 把握を行った。調査は 2014 年 7 月、2014 年 $8 \cdot 9$ 月、2015 年 $5 \cdot 9$ 月、2016 年 $2 \cdot 9$ 月の 6 回、ハノイで行った。

\section{3 ベトナム都市部の住宅生産の概要}

住宅建設数について、UN-Habi tat 文 ${ }^{6)}$ の推計によると、ベトナム 都市部では、1999 年から 2009 年の間に約 270 万戸の住宅が供給さ れた注 4)。このうち約 160 万戸は低所得者向けの平屋の小規模な住宅 と推計されており、本研究が対象とする 5 階建て程度のペンシル住 宅は中流層向けといえる。

加えて、UN-Habitat の報告では、都市部の住宅ストックの $80 \%$ 程 度は持家と推定されており、この住宅ストックの約 $75 \%$ は、住民が 自らの資金を使い、小規模な請負会社や職人を雇って供給するもの としている注5)。本研究で取り上げる躯体チームはこのような住宅生 産において躯体工事の労務提供を行うものであり、躯体チームを調 べることで八ノイの住宅生産の一般的な有り様を調べることができ る。

尚、ベトナムの建築・住宅関連法規としては、設計基準と材料規 格等が一体となった建設基準法、住宅の所有や売買について定めた 住宅法、建設行為や建設許可に関わる建設業法およびそこから派生 した品質基準、法人登録制度等がある文8)。ただし、本研究で扱う躯 体チームの多くは法人化していないため建設業の登録はしておらず、 行政による統計等から実態を把握することは困難である注6)。
本稿は既発表論文文りを加筆・修正したものである。

東京大学大学院 特任准教授・博士 (工学)

( ₹ 113-8656 文京区本郷 7-3-1)

芝浦工業大学 教授・博士 (工学)

東京大学大学院 研究員・博士 (工学)
Project Assoc. Prof., The Univ. of Tokyo, Dr. Eng.

Prof., Shibaura Institute of Technology, Dr. Eng.

Researcher, The Univ. of Tokyo, Dr. Eng. 


\section{2. ペンシル住宅の構法的特徵}

\section{1 ペンシル住宅の概要}

ハノイの一般的なペンシル住宅は $50 \mathrm{~m}^{2}$ 程度の細長い敷地に建つ、 5 階程度の鉄筋コンクリート造の住宅である（写真 1 、図 1)。細長 い敷地に建つため奥行き方向奥か中央に階段を配置して、階段の前 後か道路側に部屋を設けるなど、プランのバリエーションは限られ る文2)。隣家と外壁同士が接する場合も多く、1 階が商店や飲食店に 使われる場合も多い。住宅が面寸る道路は狭い場合も多く、後述す るように施工や材料運搬の制約となっている。篠崎ら文 3 も も指摘する ように前面ファサードにはコロニアルなヴィラを意識した装飾がほ どこされる場合が多い。

\section{2 ペンシル住宅の躯体材料・法}

ペンシル住宅の躯体は鉄筋コンクリート造の柱・梁からなり、標 準的な断面は柱 $220 \mathrm{~mm}$ 角、床厚 $100 \sim 120 \mathrm{~mm}$ 程度である。柱が 220 mm角であるのは、内外壁のレンガ（110 mm幅）を 2 重に積んだ厚さ と揃えるためである。柱は敷地の奥に向かって両側に建てられ、敷 地の奥行き方向の断面は $220 \mathrm{~mm}$ よ大きい場合もある。間口方向の 断面を大きくした方が間口方向に梁をかける上で有利であるが、室 内を広く使うため奥行き方向の断面を増やしたと考えられる。梁の 幅も $220 \mathrm{~mm}$ に揃えられる場合が多い。

スラブは $100 \sim 120 \mathrm{~mm}$ が多いが、近年では要求性能の高い施主の場 合等に床厚を $150 \mathrm{~mm}$ にする場合も見られる。床の厚さに関して「鉄 筋を 2 重にする場合 $150 \mathrm{~mm}$ とする（C1 社）」、「床厚を $100 \mathrm{~mm}$ とする 場合 $8 \phi$ の鉄筋を使い、120 mmでは $10 \phi$ を使う (C2 社)」といった 使い分けも見られた。寸法はメートル法が使われている。階高の寸 法等を風水によって決定する場合も見られる。

壁下地はレンガが使われる。コンクリートブロックもオフィスや マンション工事では用いられるが (C3 社)、対象とした 10 躯体チ 一ムの住宅では使用は見られなかった。外壁レンガは 2 重が多く、 間仕切りは 1 重が多い。複数の施工会社、躯体チームインタビュー において、室内が狭くなることを嫌い外壁も 1 重壁とする住宅が増 加していると指摘があった。先述のように、外壁を隣家と接して設 置する場合も多いが、隣家と接する部分の外壁の外部仕上げは行え ない (写真 2$)$ 。そのため、隣家を解体した際には外壁から雨漏りを する場合も見られる。レンガには大きく分けて孔空きレンガと孔無 しレンガがあり、ハノイ市内でも製造されている。孔空きレンガは 1100 ドン／個程度（180 ドン $\fallingdotseq 1$ 円）で主に間仕切りや軽量にした い片持部分の外壁に使われ、孔無しレンガは 1500 ドン／個程度で 外壁に使われる場合が多い注 8)

\section{3 ペンシル住宅の躯体施工法}

コンクリート型枠は躯体チームが用意するのが一般的であり、木 の型枠、鋼製型枠双方が使われる。木の型枠は $15 \mathrm{~cm}$ 程度の幅の板 や合板が使われる。床の型枠では、合板や鋼製型枠で大まかにふさ いだ後、隙間を板でふさぐ。特に木の型枠の精度が低いため、隙間 をビニール等のシートで目張りすることも行われる（写真 3$)$ 。

鋼製型枠は 2010 年頃から使い始めたと B5 チームは述べた。B3 チームは柱と床には鋼製型枠、梁には木製型枠を用いると述べ、B1 チームは規模の大きな工事では鋼製型枠を使うと述べるなどチーム によって型枠の使い分けも見られる。

都市部では躯体チームが型枠の保管場所を持っていないため、型
枠はリースが一般的である。リース価格は延床面積あたり $8.5 \sim 9$ 万ドン / $\mathrm{m}^{2}$ である。郊外の $\mathrm{B} 3$ チームや $\mathrm{C} 2$ 社では躯体チームや施 工会社が型枠の保管場所を持つため型枠のリースは行われない。

ハノイでは狭小敷地・街路が多く、住宅工事のコンクリートは小 型ミキサーを使い現場で練り混ぜる場合が多い。生コン（レディー ミクストコンクリート) プラントもあり、B2、B8 チームは、スラ ブ打設時など大量に打設する場合は生コンを用いると述べた。コン クリート打設時にはバイブレーターも使われる。かぶり厚さ確保の ためには、モルタルで自作したスペーサーを型枠と鉄筋の間に挟む。 かぶり厚さは 20〜25 mm程度である。工程は柱を打設し、レンガ壁 を設けた後、梁とスラブを同時に打設する。

足場や支保工は木製で細い堅木が使われる。外部はレンガの隙間 に足場の腕木を差し込んだり、Y 型の木材で型枠を支えるといった 工夫も見られる (写真 4)。総じてコンクリートの精度は低いがレン ガやモルタルによって誤差を吸収している。

\section{4 ペンシル住宅の仕上げ等}

壁面はレンガ壁に厚さ $20 \mathrm{~mm}$ 程度のモルタルを塗り、ペンキで仕 上げる。天井は直に塗装するか石膏ボードを下地とする場合が多い。 石膏ボードは $9 \mathrm{~mm}$ 厚の $4 \times 8$ 版 $(1,200 \times 2,400 \mathrm{~mm}$ 程度 $)$ が流通して おり、下地枠には軽量鉄骨を用いる。開口部はシングルガラスのア ルミサッシが多い。床はタイルを用いる場合が多い。

八ノイでは、冬期に $12 \sim 15$ 度程度まで気温が下がり湿度も高い ため頻繁に結露が発生するが、断熱材はほとんど用いられていない 注 9)。居住面積の増加と温熱環境の向上を意図して、屋上部に増築を 行う場合も多く見られる。こうした増築は鉄骨で骨組みを造り、ト タンの屋根を敷く場合が多い。こうした増築の費用は 1000 万〜 3000 万ドン程度である（写真 5 )。

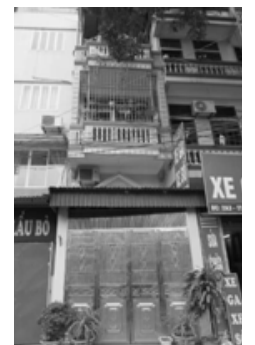

写真 1 ペンシル住宅
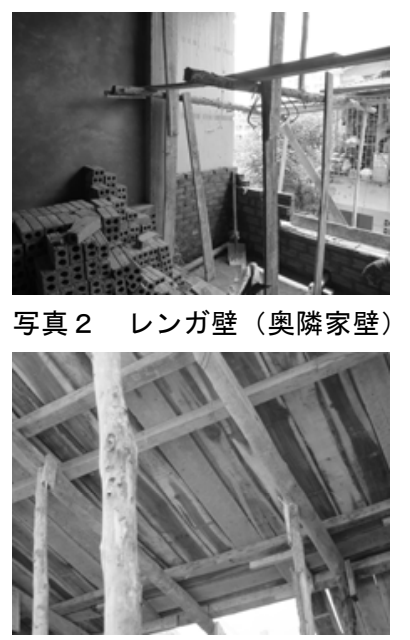

写真 4
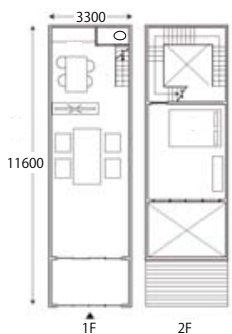

図 1 同住宅の平面概要注

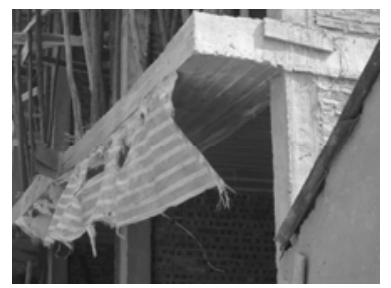

写真 3 目張りシート

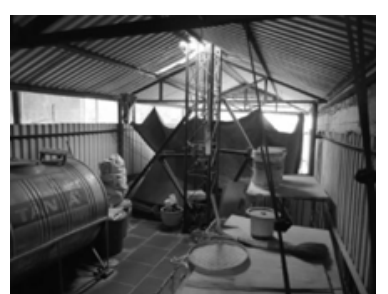

写真 5 屋上増築 


\section{3、ペンシル住宅の生産体制}

\section{1 職種編成・躯体チームの体制}

ペンシル住宅の施工において、躯体チームは基礎、柱、梁、床、 レンガ、下地の左官、壁に埋め込む空枠等までの施工を担当する。 また、多くの場合、躯体チームがタイル工事も手がけるが、石工事 は別の職人が行う。躯体チーム以外の職種として、解体、杭、土工、 ガラス、石、防水、ボード、叙装、建具、スチール (門・階段等)、 フローリング、設備（電気、水道は都市部では別）等が施工に関わ る。躯体チーム以外の職種を躯体チームが手配することもあるが、 施主が他職種を選ぶ場合が多い。

敷地面積 $50 \mathrm{~m}^{2}$ 程度のペンシル住宅の躯体は $5 \sim 10$ 人程度の躯体 チームで施工する。建物の高さや平面計画に大きな差はないため、 一般に職人の労務量は敷地面積を元に計算される。B1 チームでは、 1 現場あたりの人数を、敷地面積 $5 \mathrm{~m}^{2}$ に付き職人 1 人と計算する。 敷地面積が狭い場合、職人の数が多いと作業がしづらくなり施工性 が下がるという意見も見られた。

$\mathrm{C} 1$ 社は、手がける住宅の敷地面積が $100 \mathrm{~m}^{2}$ などと比較的大きな 場合、15 名程度の躯体チームで躯体を施工寸る。この場合、躯体チ 一ムは配筋、型枠、レンガ・左官の 3 職種に分けられる。一般建築 を施工する施工会社 C3 社の施工現場でも型枠、配筋、打設は別職 種である。尚、C3 社は住宅工事の施工は行わない。

施主は地縁血縁や紹介等で躯体チームに施工を依頼する。小規模 な躯体チームは八ノイの中でも特定の地域に限って施工を行う。見 本となる家を施主が指定し、それと類似の仕様で躯体チームが実質 的な設計を行う場合も多い。先述のように住宅平面は画一的であり、 仕上げ等を施主が指定すれば設計の大半は完了する。

\section{2 契約}

施主と躯体チームは契約書を作成する。契約書の例（A1 事務所） を表 1 に示す。これは設計事務所の例であるが、他躯体チームも施 主との間で契約書を作成すると述べた。契約書の内容は工事概要、 施工期間、契約額・支払い方法、当事者の責任等からなる。材料の 支給や職人の住居確保は施主の責任であると書かれており、契約金 額は面積当たりの労務単価に床面積をかけて計算する。設計変更に よる工期延長の人件費（1 人工 27 万ドン）や、斜めの床の場合の労 務費割り増し（1.5 倍）も定めている。

一般にペンシル住宅は施主が各工事について施工を分離発注する。 また、後述するように躯体工事の材料は施主支給が一般的である。 インタビューを行った中では、施工会社 $\mathrm{C} 1$ 社のみ材工一式かつ躯 体以外の専門工事も含めた一式請負を行う。設計事務所 3 社のイン タビューでも、施主が各工事を分離発注し、躯体工事は材工分離で の住宅生産が一般的との回答が得られた。

躯体工事において材工分離の住宅生産が広く行われる理由は、口 アン文4)も指摘するように、施主・躯体チーム相互に信頼関係がなく、 施主にとっては低質の材料を使われるリスク、施工者にとっては代 金回収のリスクがあるためと考えられる。一方で近年は、躯体チー ムが施主の親戚の場合などに、材工一式の躯体工事も行われ、材工 一式の工事が増加しているとの意見も見られた。後述のように、1 チームではなく複数チームを管理するリーダー、あるいは $\mathrm{C} 1$ 社の ような施工会社では、比較的資金に余裕があり、施主からの信頼も あるため、他職種を含めた一式請負のような形態も可能になると考
えられる。図 2 にインタビューを元にした標準的なペンシル住宅の 生産体制をまとめた。

施主は躯体、ガラス、ボードなど工事ごとに施工会社や施工チー ムに依頼する。躯体に関して、(1)施主は躯体チームのリーダー（タ 力、後述）と直接契約する場合、(2)複数の躯体チームを束祆る労務 仲介者（ニャータウ、後述）に依頼する場合、(3) C1 社のように施 工会社と躯体以外の職種も含めた一式請負の契約をする場合、の 3 パターンが見られた。(1)のタカは自ら現場作業を行うが、(2)のニャ 一タウは現場作業を行わず、施主との契約や施工現場の管理を行う。 B1 チーム、B6 チームのリーダーはニャータウにあたり、自ら職人 の経験はないが、施主との契約や賃金等の管理、道具の貸し出し、 施工上の助言（精度を高める方法など）などを行う。

\section{表 1 契約書の内容}

冒頭：根拠法、当事者の住所・連絡先等 第 1 条 (工事概要)：工事建物の住所、構造、階数（詳細は図面参 照とのこと)

第 2 条（施工期間）：工期、遅延した場合の対応

第 3 条（契約額・支払い方法）：面積当たりの労務単価（斜めの床 は 1.5 倍で計算)、施工範囲（基礎、柱、壁、床、レンガ、左官、 タイル）、施主負担（生コンクリート、基礎掘削工事など）、施工 者の範囲外工事（電気、水道、仕上げ塗装、手摺、扉、階段の夕 イル)、設計変更の場合の追加労務費（1人・日 27 万ドン）、契約 時前払い金 1000 万ドン、基礎コンクリート打設後 2000 万ドン、 1 ～5 階天井打設後各 2000 万ドン、1 5 階仕上げ終了後各 2000 万 ドン、残額は工事終了後 15 日以内に支払う

第 4 条（当事者の責任）：施主の責任（現場まで資材を提供する、 職人の帯在の登録許可を取得する、工事の監督のための人員を配 置する、職人の住居費 2 ヶ月分など)、躯体チーム（施工の安全、 足場・型枠の手配、近隣対応、施エミスの場合の自己負担でのや り直し、など) 第 5 条 (一般事項) : 署名、問題時対応

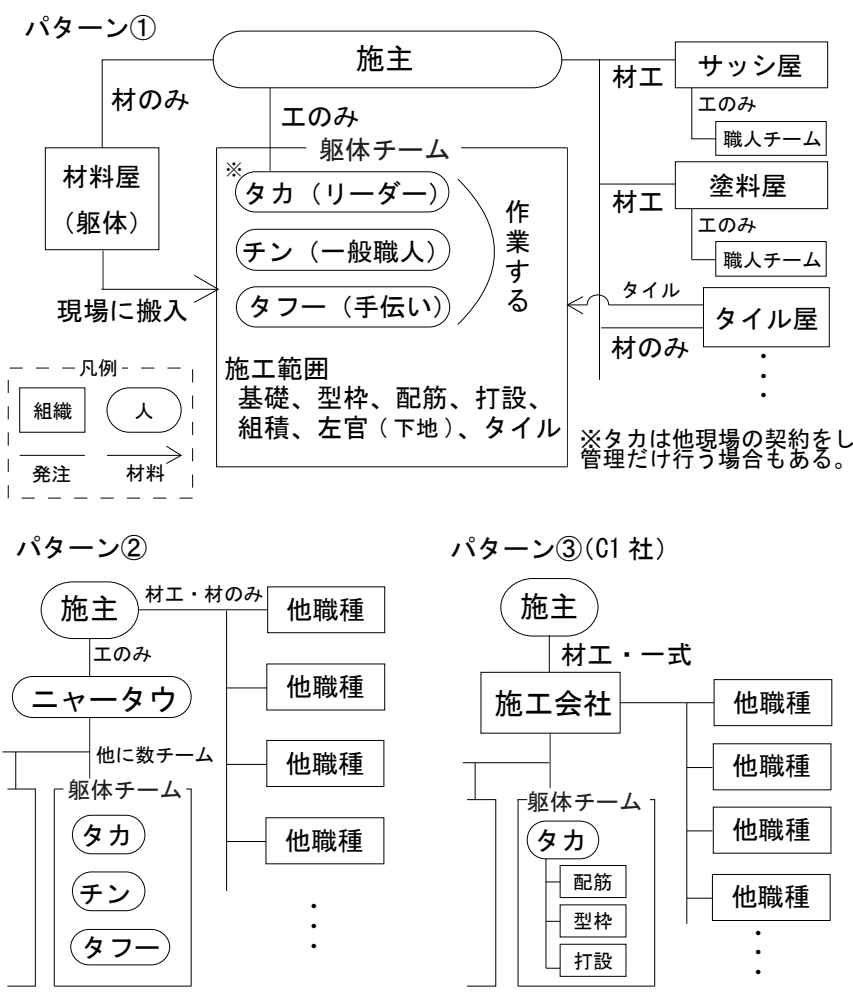

図 2 ペンシル住宅の施工体制 


\section{3 費用 $\cdot$ 工期}

躯体工事の労務費（型枠リース代含む）は 80～100 万ドン $/ \mathrm{m}^{2}$ 程 度、材工一式の場合の躯体工事施工費は $300 \sim 400$ 万ドン $/ \mathrm{m}^{2}$ 程度 である。住宅ローンの使用は見られない。B7 チームは狭い敷地の 場合、施工が難しく面積当たりの柱や壁の量が増えるため、 $50 \mathrm{~m}^{2} の$ 敷地では 90 万ドン $/ \mathrm{m}^{2}$ 程度、 $30 \mathrm{~m}^{2}$ の敷地では 120 万ドン $/ \mathrm{m}^{2}$ 程度 を目安にする。住宅を中心に設計する A1、A2 事務所の設計料は 50 万ドン $/ \mathrm{m}^{2}$ 程度であり、施工監理までは行わない場合が多い。

ペンシル住宅の躯体の一般的な工期は $3 \sim 6$ ヶ月で、コンクリー 卜打設日を縁起の良い日とする場合や、農業の繁忙期に職人が 1,2 週間程度農村に帰ることで工期が延びる場合もある。工期の算出方 法について躯体チームにたずねると、平均 3 ケ月、1 フロア 12 日と いった大まかな計算が多い。一方で、施工会社 $\mathrm{C} 1$ 社では、 3 人工 $/ \mathrm{m}^{2}$ で計算すると述べた。施主が工事費を支払う時期は契約により、 階毎や躯体工事・左官工事で分かれる場合もある。5 階建のペンシ ル住宅で躯体・左官に分けて支払う場合、支払いは 10 回に分けて 行われる。施主からの支払いが遅れる場合は躯体チームのリーダー やニャータウが職人の賃金を立て替える。

\section{4.施エに関わる主体}

\section{1 躯体チーム、施工会社}

躯体チーム・施工会社の概要を表 2 にまとめた。躯体チームは年 間数棟から十数棟の住宅の躯体を施工寸る。施工会社 $\mathrm{C} 1 、 \mathrm{C} 2$ 社お よび近年施工に携わり始めた B6 チームを除いて、躯体チームのリ ーダーやニャータウは高校や大学で工学教育を受けていない注 10 )。 他の躯体チームの職人、ニャータウは中学・高校卒業後や兵役後に 農村部からハノイ市に出てきて職人になった。対象とした躯体チー ムのリーダー10 名は八ノイ市周辺の農村出身である注 11)。

複数の住宅を同時に施工寸る場合、通常躯体チームのタカ（リー ダー）として活動する職人は、1 現場のみタカとして実際に施工に 加わり、他現場については施主との契約や管理のみ行う（B2 チー ムなど)。躯体チームの規模が大きくなるに連れて、リーダーは複数 の躯体チームを束㸚るリーダーのようになり、自ら現場作業は行わ ないようになる。また、小規模な躯体チームではリーダーが、他の リーダーに呼ばれて職人として現場作業を行う場合もあるが、規模 が大きくなると、自ら直接契約した工事の施工のみを行う。

\section{2 職人の構成・待遇}

躯体チームは、リーダーのタカ $\left(\mathrm{Tho} \mathrm{Ca}^{\text {注 }}{ }^{12}\right)$ )、通常の作業をす るチン（Tho Chinp）、手伝いのタフー（Tho Phu）からなる。B1 チームや B6 チームのように現場作業は行わず、施主と契約して躯 体チームの施工管理のみを行う主体はニャータウ（Nha Tau）など と呼ばれる（表 3 )。

躯体チームの職人は全員が配筋、型枠、打設、レンガ、左官等を 施工する。タフーは炊事等も行う。B3 チームによると、タフーの 割合は躯体チームの 3 分の 1 程度だが、コンクリートの機械練りな ぞの機械化によってチーム人数に占めるタフーの割合は減少してお り、以前はチームの 2 分の 1 程度がタフーだったと述べた。チーム のメンバーはおおむ称固定されており、規模が大きくなると応援の 職人を呼ぶ。同郷者でチームを構成する場合も複数見られた。ベト ナム人以外の労働者は見られない。建設現場での労働が敬遠され職

人が集まりにくくなったという意見も見られた。先述のように農業 の繁忙期には農村に帰るなど、技能を熟練することへの意欲は低い。

職人になる場合、タフーから仕事を始め、チンを経てタカとなる。 タフーからチンになる条件は施工費の計算ができる、図面が読める など、様々な基準がある。タフーからチンになるまでの期間も、タ フーから 1 年でチンになった（B5 チーム）など様々である。

職人の賃金は、タカが日給 20～30万ドン、チンが 20～25万ドン、 タフーが 12〜20 万ドン程度である。チンとタフーそれぞれの中で 2 段階に分けて賃金を決める躯体チーム、施工会社も見られた。尚、 八ノイ地域の最低賃金（2015 年 1 月改定）は 310 万ドン/月であ り、タフーと同程度の水準である。職人は社会保険に加入していな い。食事や宿泊はタカやニャータウが準備し職人は光熱費のみを負 担する。1 階の躯体が立ち上がると職人は現場に寝泊まりをする場 合もある（写真 6)。B3、B10 チームのように郊外の現場では、自 宅から現場に通うため食費・宿泊費は賃金に組み込まれない。職人 安全意識は低く、半袖、半ズボン、足下はビーチサンダルで、ヘル メットを着用した職人もほとんど見られない（写真 7)。施工道具や 機械はタカやニャータウが所有している。

表 2 躯体チーム・施工会社概要

\begin{tabular}{|c|c|c|c|c|}
\hline \begin{tabular}{|l|} 
チーム名· \\
会社名 \\
\end{tabular} & \begin{tabular}{|l|} 
タカ·経営者 \\
生年·出身地
\end{tabular} & 年間施工棟数 & \begin{tabular}{|l} 
躯体工事 \\
労務費単価 \\
\end{tabular} & チームの人数 \\
\hline B1チーム & 1973年·ニンビン省 & 15棟程度 & 90〜100万ドン / $\mathrm{m}^{2}$ 程度 & 10名程度 \\
\hline B2チーム & 1970年・バクザン省 & $\begin{array}{l}\begin{array}{l}\text { 4棟程度 } \\
\text { (最低2棟) }\end{array} \\
\end{array}$ & 90 万ドン / $\mathrm{m}^{2}$ 程度 & 5名程度 \\
\hline B3チーム & |1968年·タイビン省 & 12 棟程度 & 80 万ドン / $\mathrm{m}^{2}$ 程度 & $\begin{array}{l}\text { 通常3名程度で打 } \\
\text { 設等では増員 }\end{array}$ \\
\hline B4チーム & 1973年·ナンビン省 & 4棟程度 & 90 万ドン / $\mathrm{m}^{2}$ 程度 & 7名程度 \\
\hline B5チーム & 1970年·タイビン省 & 6, 7 棟程度 & 95 万ドン $/ \mathrm{m}^{2}$ 程度 & 6名程度 \\
\hline B6チーム & 1982年·タイビン省 & $\begin{array}{l}\begin{array}{l}\text { 棟程度(他に } \\
\text { 改修) }\end{array} \\
\end{array}$ & 90 万ドン $/ \mathrm{m}^{2}$ 程度 & 10名程度 \\
\hline B7チーム & 1972年・バクニン省 & 8棟程度 & 90万ドン / $\mathrm{m}^{2}$ 程度 & 8名程度 \\
\hline B8チーム & 1977年·ニンビン省 & $\begin{array}{l}\text { 棟程度 (改修 } \\
\text { 含む) } \\
\end{array}$ & 90 万ドン $/ \mathrm{m}^{2}$ 程度 & 8名程度 \\
\hline B9チーム & 1984年・フート省 & $\begin{array}{l}\begin{array}{l}\text { 棟程度(他に } \\
\text { 改修) }\end{array} \\
\end{array}$ & 100 万ドン / $\mathrm{m}^{2}$ 程度 & 7名程度 \\
\hline B10チーム & 1970年·フンエン省 & 4, 5棟 & 80 〜 100万ドン $/ \mathrm{m}^{2}$ & 6名程度 \\
\hline C1社 & 1973年·カムニン省 & 15棟程度 & 材エー式で仕上げまで & $\begin{array}{l}\text { 12名程度、型枠、配 } \\
\text { 筋、打設に分かれる } \\
\end{array}$ \\
\hline C2社 & 1987年・ハイズオン省 & \begin{tabular}{|l}
10 棟程度 \\
(内装含む)
\end{tabular} & 100 万ドン / $\mathrm{m}^{2}$ 程度 & 8名程度 \\
\hline
\end{tabular}

※躯体工事労務費単価、チームの人数は建築面積 $50 \mathrm{~m}^{2}$ 程度、5階建程度の住宅を施工する場合

表 3 職人の名称 - 分類

\begin{tabular}{|c|c|}
\hline 名称 & 概要 - 待遇 \\
\hline $\begin{array}{c}\text { タカ } \\
\text { (Tho Ca) }\end{array}$ & $\begin{array}{l}\text { 躯体チームのリーダーで自ら施エも行う。施主と直 } \\
\text { 接契約も行う。日給 } 20 \sim 30 \text { 万ドン程度 }\end{array}$ \\
\hline $\begin{array}{l}\text { ダオカイン } \\
\text { (Tho Dau Canh) }\end{array}$ & $\begin{array}{l}\text { 工事が部門毎に分かれる場合の各部門のリーダー。 } \\
\text { 日給 20〜23 万ドン程度 }\end{array}$ \\
\hline $\begin{array}{c}\text { チン } \\
\text { (Tho Chinp) }\end{array}$ & $\begin{array}{l}\text { タカもしくはダオカインの下で実質的に施エを行 } \\
\text { う。日給 } 20 \sim 25 \text { 万ドン程度 }\end{array}$ \\
\hline $\begin{array}{l}\text { タフー } \\
\text { (Tho Phu) }\end{array}$ & $\begin{array}{l}\text { 炊事や清掃等の雑用を行う。躯体チーム内の } 3 \text { 分の } 1 \\
\text { 程度を占める。日給 } 12 \sim 20 \text { 万ドン程度 }\end{array}$ \\
\hline
\end{tabular}

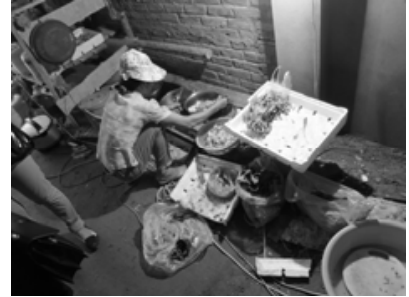

写真 6 施工現場での調理

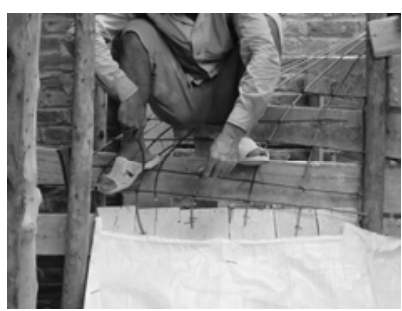

写真 7 サンダル履きで鉄筋結束 


\section{3 材料流通業者}

躯体工事に関係するレンガ、鉄筋、セメント等を扱う材料流通業 者 4 者にインタビューを行った。4 者とも法人化していない。材料 流通業者はレンガやセメントをメーカーから仕入れて施主に販売す る。4 者ともレンガ、砂、砂利、セメント、鉄筋、型枠を扱ってお り、住宅以外の一般建築工事にも材料を供給する。4 者のうち八, イ市中心部の 2 者は型枠のリースも行っており、解体や土工事も手 がける。問屋を介することは少なく、レンガやセメントは工場やメ 一カーから購入している。材料流通業者が図面から数量を拾うこと は行われておらず、施主から指定された量の材料を納品する。レン ガやセメントはおおむね在庫で対応でき、工場から購入する場合で も 1,2 日で納品できる。個人との取引は現金で行い、月末などにま とめて支払う。材料価格は変化が大きく、その変動に追従する契約 を行う。

都市部では施工現場が狭く置き場所がないため、材料流通業者は 1、2 日毎に材料を納品する。A1 設計事務所設計の住宅注 3)では、材 料費の支払い記録も残されている。躯体工事の材料は敷地から 500 $\mathrm{m}$ 程の材料流通業者で購入された。躯体工期 253 日中 212 日で材料 の搬入があり施主が立ち会った。このため施主（妻）は半年程度仕 事を休み対応している。材料費支払いは 24 回に分けて行われるなど 施主の負担は大きい。

施工現場への材料の運搬は、狭险な街路が多いこと、敷地が狭く 多くの材料の保管は難しいことなどから、手押し車や荷台を付けた バイクで行う場合が多い（写真 8)。材料メーカーから材料流通業者 への運搬や遠方の施工現場への運搬にはトラックが使われる。材料 の運搬費は片道 30 分程度の平坦な道を荷車で運搬する場合、 15000 ドン／回、自動車では 25 万ドン（片道 $7 \mathrm{~km}$ 程度まで）などである。 手押し車やトラックは材料流通業者が所有している。このように頻 繁に少量の運搬を行うため、ハノイ市中心部の 1 者には 50 名のワー カーがいる (中心部のもう 1 者は 8 名)。一方、郊外の材料流通業者 は基本的に自動車による運搬を行うため、ワーカーは 3 名程度、15 名程度と少ない。施工現場、材料流通業者とも材料の保管は雨ざら しの場合も見られ、管理の状況はよくない（写真 9)。躯体工事以外 の材料では、石膏ボード、配管、塗料、サッシなどは材工一式で材 料流通業者が手配した職人が施工寸る場合が多い注 13$)$ 。サッシ等で は中国、日本など様々な国の建材が使われており、性能等を比較す るのは容易ではない。材料流通業者が材工一式の工事を行う場合、 半年や 1 年といった期間、材料流通業者が保証をつける。

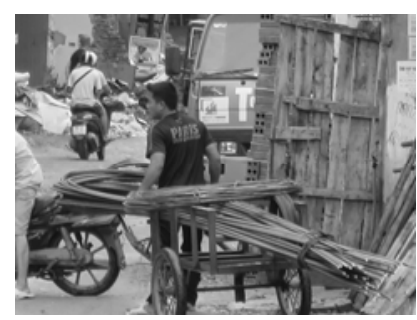

写真 8 鉄筋の運搬

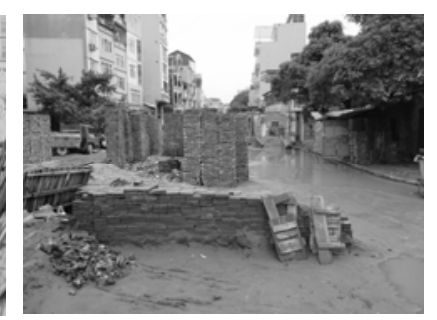

写真 9 材料保管場所

\section{5. まとめ}

本稿では、ハノイでペンシル住宅生産に関わる躯体チームや施工 会社、設計事務所、材料流通業者に対してインタビューを行うとと
もに、施工現場の調查を行い、ペンシル住宅の構法や施工法、躯体 チームを中心とした施工体制、職人の待遇、材料流通など、ペンシ ル住宅の生産システムの一端を明らかにした。

ペンシル住宅の躯体は、ベトナム以外の国でも多く見られる鉄筋 コンクリート造の柱梁とレンガ帳壁からなる。構法面の課題として、 型枠の精度が低く、コンクリートの調合やかぶり厚さ等の管理も不 十分であること、柱、梁、床などの寸法が工学的な検討なし材料寸 法等に合わせて決められていることがあげられる。一方で近年では 床厚を増やすなど、一部の施工会社や躯体チームで性能を向上させ る取組も見られる。鋼製型枠や生コンの使用も見られたが、特に生 コンは狭险な街路が多く、普及には時間がかかる可能性がある。

こうしたペンシル住宅の躯体は多くの場合、法人化していない小 規模な躯体チームが施工寸る。躯体チームは $5 \sim 10$ 人程度の職人の グループであり、躯体工事の労務のみを提供する。職人はリーダー のタカ、一般的な職人であるチン、手伝いをするタフーから構成さ れる。施主と施工者との関係は、施主がタカと労務のみの契約を行 う場合、施主は複数の躯体チームを束ねるニャータウと契約する場 合、法人化した施工会社が材工一式かつ他職種を含めた一式請負を 行う場合の 3 パターンが見られた。躯体チームの手がける施工範囲 は基礎から型枠、配筋、打設、左官、タイルまでと幅広いが、同じ 職人が全ての工事をこなす。インタビューを行った躯体チームのタ カは全てハノイ周辺の地方出身者であり、タフーから職人の仕事を 始めて、図面の読み取りや契約、支払いの計算等を行えるようにな ってタカとして独立している。

生産組織面の近年の変化として、躯体チーム、職人の減少や、コ ンクリート練りの機械化によるタフーの減少などが指摘された。ま た、施工会社や比較的大規模な躯体チームによる材工一式での一式 請負に増加の兆候が見られることが指摘された。住宅を主に手がけ る施工会社 2 社は、他躯体チームと比べて労務量の計算方法や躯体 工事の分業化（型枠、配筋、打設）など施工管理手法の改善が見ら れる。今後、住宅の品質や性能に対寸る要求が高まれば、比較的大 規模な躯体チームや施工会社らの優位性が高まる可能性がある。

ペンシル住宅の躯体工事に関しては材工分離の生産が一般的であ り、施主は材料流通業者から材料を調達する。狭险な街路、敷地が 多いため、材料流通業者は頻繁に材料を敷地まで搬入し、施主はこ の受け取り等に多くの労力をさく。先述のように材工一式による住 宅生産が広がれば、材料の管理までを含めた住宅の品質向上やコス トコントロールも可能になり施主の負担も軽減されるが、住宅金融 の整備や施工者への与信のシステム構築が今後の課題となる。躯体 工事以外の材料の多くは材工一式で材料流通業者が手配した職人チ 一ムが行う。品質や問題が起こった場合の保証はメーカーや材料流 通業者が自主的に行っている場合も見られるが、今後整備を進める 必要性がある。

\section{謝辞}

本研究は JSPS 科研費 15K18183、26289216 の助成を受けたもので す。インタビュー調查でご協力いただいた方、調査に同行いただい たトラン・ダイ・ギア氏、渡辺千晴さん、岡安大地君、大下宏樹君、 市川大暉君、黒坂雅人君に感謝いたします。 


\section{参考文献}

1）渡辺千晴, 権藤智之, 蟹澤宏剛, 志手一哉, 金容善, 岡安大地, ベトナ ムにおける町場の建築生産システムに関する研究, 第 31 回建築生産シン ポジウム論文集, pp. 161-166, 2015 年 7 月

2）佐々木誠, 友田博通, 花里俊廣, 石井希, 河田彩子, 西智裕, ペンシル ビル住宅の現状と可能性-ベトナム・ハノイにおける都市住宅に関する研 究 その 3 -, 日本建築学会大会学術講演梗概集 (九州) 計画, pp. 13-14, 1998 年 9 月

3）篠崎正彦, 友田博通, 内海佐和子, ベトナム都市住宅調查概要一ハノイで の事例を中心として-, 昭和女子大学国際文化研究所紀要 No. 777, pp. 135-144, 2005 年 7 月

4）ロアン・ファン・チュイ, 西村幸夫, ベトナム・八ノイ市における自力 建設住宅 住宅供給システムの構造と住宅地の環境についての研究, 日 本建築学会計画系論文集, 第 578 号, pp. 123-130, 2004 年 4 月

5）岡安大地, 蟹澤宏剛, 権藤智之, 金容善, ベトナムにおける日韓の生産 方式に関する比較研究, ベトナムにおける日韓の生産方式に関する比較 研究，第 30 回建築生産シンポジウム論文集，pp. 85-90, 2014 年 7 月

6) UN-Habitat, Vietnam Housing Sector Profile, 2014 年 6 月

7）佐貫大輔, 西澤俊理, ベトナム建築奮闘記, JIAMAGAZINE, 278 号, pp. 12, 2012 年 3 月

8）独立行政法人国際協力機構, 株式会社日建設計総合研究所, 株式会社 UR リンケージ，ベトナム国住宅セクター基礎情報収集・確認調査, 2014 年 2 月

9）大下宏樹, ベトナム・ハノイ市における庶民住宅生産に関する研究-ペン シルハウス生産の実態と住まわれ方調査-, 首都大学東京大学院修士論文, 2017 年 3 月

注

1）ロアンが対象とした 36 棟では、施工のみを工事会社に依頼し、設計、材 料調達、施工管理は施主自らが行う方式が $58 \%$ (21 棟)、建築家が設計 し、施工会社が施工と施工管理を行うが、施主が材料支給を行う方式が $31 \%$ （11 棟）を占めるなど、施主が材料支給や施工管理を行う割合が高 い(文献 4)。

2）岡安らは、日本と韓国のゼネコンのベトナムにおける建築生産体制を比 較する中で住宅生産についても部分的に扱っている（文献 5)。

3）対象住宅は、設計事務所 A 社が設計し 2012 年に建設された 5 階建てのぺ ンシル住宅である。本研究が主に対象とする、施主が躯体チームのリー ダー等と相談しながら設計する生産体制とは異なるが、躯体の寸法や材 料は他の調査対象としたペンシル住宅と変わらず、躯体チームへの依頼 内容や材料調達の方法については大きな違いがないと考えられる。

4） UN-Habitat の推定では、1999 年から 2009 年の間に 273.5 万戸の住宅が 都市部に供給された。このうち約 160 万戸は平屋の小規模な住宅と推定 されている。ベトナムの持家の割合（2009）は $86.1 \%$ 、都市部の同割合 は $80.8 \%$ としている（文献 6、p. 17)。本稿で取り上げる 5 階建て程度の ペンシル住宅は、佐貫も指摘するように中所得者層に向けた住宅と言え る（文献 7)。また、高所得者層に向けた住宅としては、ハノイ市近郊で も近年、住宅地全体を塀で囲った戸建住宅（ヴィラ）の住宅地開発が見 られる。

5） 2012 年の水準で、 $60 \mathrm{~m}^{2}$ の住宅の建設費（仕上げ等含む）は 7 億ドンで、 これは上位 5\%の消費者のみ購入可能とされている（文献 6、p. 17）。

6) 研究機関インタビューでは、マンションやアパート建築の増加によって 法人化した施工会社が住宅工事を担う割合が高くなり、ハノイ市の躯体 チーム数は減少傾向にあると指摘された。

7）図 1 は文献 9 (p. 35) から転載した。ハノイ市の同住宅は 2000 年に建設 された。建物奥に階段やトイレ、キッチン（1階のみ）がある。2階から 4 階はそれぞれ 1 部屋のみ居室がありベッドが置かれている。屋上は竣 工後に増築し屋根壁ともトタンで囲われている。1 階はかつて店舗とし て使われていたため天井高が他階より高い。

8）他に見られた工夫として、B10 チームでは外壁レンガを積む際、孔空き レンガは室内から見て長手方向に積み、孔無しレンガは小口方向を見せ て積む。これによって外部から水を進入しにくくしつつ、コスト削減や 外壁の軽量化を図っている。

9）設計事務所 A1 社設計の住宅で西側の外壁内部に発泡系断熱材のボード が用いられた例が 1 例のみ見られた。
10) C1 社で施工を担当する副社長のDuc 氏のみ大学で建築教育を受けている。 また、同社で複数現場を管理する Thi 氏は建築系の専門学校を卒業した 後、職人となり現在は同社の社員である。施工会社 C2 社の Duy 氏は工学 系の大学を卒業したが建築教育は受けておらず、建築業界の将来性を見 越して同年代の 4 名で住宅施工の会社を設立した。

11）ベトナムを 8 地方に分割した場合、ハノイは紅河デルタ地方に位置する 中央直轄市である。躯体チームリーダーの出身地のうち、ニンビン、タ イビン、バクニン、フンエンの各省はハノイ市と同じ紅河デルタ地方、 バクザン、フートの 2 省は紅河デルタ地方と東北側で接する東北地方に 属する。

12）各用語は、Tho は職人、Ca が最上・一番上、Chip が主要な・メインの、 Phu が副・サブの、Dau が頭・トップ、Canh が係・部署といった意味で ある。木造住宅など工事が複数部門に分かれる場合はタカの下にダオカ イン（Tho Dau Canh）が部門毎におり、チンに指示する。

13）インタビューを行った躯体以外の 6 材料流通業者のうち、石膏ボード、 サッシ、配管は通常材工一式で取り付けまで行う。塗料は施工まで行う 割合が 4 割程度と答えた。タイルはタイルの販売のみで施工は行わない が、これは躯体チームが施工するためと考えられる。断熱材は住宅での 使用がそもそも少なく、工場の屋根や配管向けに材料の販売のみを行う。

[2017 年 6 月 7 日原稿受理 2017 年 8 月 7 日採用決定］ 